\title{
Progress in Copper Complexes as Anticancer Agents
}

\author{
Redouane Tabti ${ }^{1,2}$, Nassera Tounsi ${ }^{1}$, Christian Gaiddon ${ }^{3}$, Embarek Bentouhami ${ }^{\star}$ and Laurent Désaubry $^{1,4^{\star}}$ \\ ${ }^{1}$ Laboratory of Therapeutic Innovation (UMR 7200), Faculty of Pharmacy, University of Strasbourg - CNRS, IIIkirch, France \\ ${ }^{2}$ Faculty of Technology, University Ferhat Abbas, Sétif, Algeria \\ ${ }^{3}$ UMR_S 1113, Molecular Mechanisms of Stress Response and Pathologies, INSERM, Strasbourg, France \\ ${ }^{4}$ Sino-French Joint Lab of Food Nutrition/Safety and Medicinal Chemistry, College of Biotechnology, Tianjin University of Science and Technology, Tianjin, 300457, China
}

\begin{abstract}
The clinical success of cisplatin has stimulated the quest for novel anticancer metallodrugs during the last two decades. A major emphasis has been put on copper due to its selective cytotoxicity toward malignant cells. This selectivity stems from the hypoxic environment of cancer cells that promotes the reduction of $\mathrm{Cu}(\mathrm{II})$ to $\mathrm{Cu}(\mathrm{I})$, leading a pro-apoptotic oxidative stress. At the current time, two copper complexes have reached clinical assay, which paves the road to the first copper-based anticancer therapeutics.
\end{abstract}

Keywords: Cancer; Copper; $\mathrm{Cu}$-complexes; Metallodrugs; Oxidative stress; Elesclomol

\section{Introduction}

The advent of targeted therapies, i.e., small molecules or antibodies that interfere with signaling proteins involved in the etiology of cancer, revolutionized the treatment of tumors with an addiction to specific oncogenes (e.g., ALK in lung cancer, Bcr-Abl in chronic myeloid leukemia, KIT in GIST, EGFR in lung cancer, HER2 in breast cancer or MET in liver tumors). However, for many cancers, the progressionfree survival of patients treated with targeted therapy is less than one year, which justify for a regain of interest in cytotoxic agents including metallodrugs [1]. Indeed, the prevalent success of cisplatin in the treatment of various types of cancers has placed organometallic compounds on the forefront in the development of anticancer drugs. In this quest, copper derivatives hold promising opportunities due to opportunities provided by the hypoxic environment that is a hallmark of cancer cells coupled with the ability of copper complexes to catalyze the formation of Reactive Oxygen and Nitrogen species (ROS and RNS) [2].

\section{Role of Copper in Physiology and in Cancer Physiology}

Tumors display a lack of blood vessels that results in a low oxygen level, which promotes invasion, metastasis and a metabolic shift to an anaerobic process known as the 'Warburg effect' [3]. Gratefully, tumor hypoxia can be exploited to develop prodrugs that become activated in the reducing environment of cancer cells. In this regard, copper is very appealing because it can exist under two different oxidation states in cells. The anoxic character of cancer cells promotes the reduction of $\mathrm{Cu}(\mathrm{II})$ to $\mathrm{Cu}(\mathrm{I})$, which is not possible in normal cells and thus provides a therapeutic opportunity to target tumors [2]. $\mathrm{Cu}(\mathrm{I})$ can catalyze the formation of ROS and RNS, to induce a pro-apoptotic oxidative stress. In addition, the redox state of copper modulates its affinity to ligands: copper(I) is a softer Lewis acid than copper(II) and displays a high affinity toward sulfur ligands, whereas copper(II) preferentially coordinates to nitrogen and oxygen donors in proteins and DNA [4].

Not only copper salts are much less toxic than platinum derivatives, but they are necessary to the organism. Indeed, the physiological concentration of copper in the body is highly regulated by several mechanisms that involve ceruloplasmin and albumin in the liver to regulate blood levels and also copper transporter proteins (CTR1 and Cu ATP7A/B) at the cellular level [4]. Due to its ability to oscillates between oxidized and reduced states in biological medium, copper acts as a co-factor for enzymes involved in energy metabolism (cyt. C oxidase), destruction of ROS (superoxide dismutase 1), melanin synthesis (tyrosinase), dopamine synthesis (dopamine- $\beta$ hydroxylase), cross-linking of collagen and elastin (lysyl oxidase). However, an excess of copper may be toxic also to non-cancer cells due to the generation of ROS and NOS, which explains why copper homeostasis is highly regulated (Table 1) [5-31]. Importantly, many types of tumors accumulate abnormally high concentrations of copper, and the concentration of copper in serum is almost doubled in breast cancer patients [32-36]. These observations may be explained by the involvement of copper in tumor growth and survival through several mechanisms. First, copper is essential to angiogenesis, which is necessary for tumor growth and metastasis. More precisely, copper sulfate induces the expression of HIF-1a, the G-protein estrogen receptor (GPER) and VEGF in breast and hepatic cancer cells through the activation of the EGFR/ERK/c-fos pathway [37]. Second, copper inhibits the apoptosis of cancer cells by binding to the XIAP protein to promote its anti-apoptotic activity [38,39]. Third, copper interacts with MEK1 to promote the phosphorylation of ERK and oncogenesis $[40,41]$. Fourth, coper activates the pro-survival phosphoinositide 3'-kinase (PI3K)/Akt pathway [42,43].

\section{Anticancer Copper Complexes}

Except for the complexes that are based on the anticancer natural product Paullone (Figure 1) [44], a majority of the cytotoxic $\mathrm{Cu}$ complexes were originally designed for their chemical and physical properties [1]. As a consequence, many of them do not exhibit druglike properties and significant anticancer effects in vivo.

The synthesis, design, and development of copper complexes as anticancer agents have been presented in several reviews over the last decade [45-52]. We focus therein on the in vivo anticancer activity of this type of drugs and include recent advances, which were not covered

*Corresponding authors: Laurent Désaubry, Laboratory of Therapeutic Innovation (UMR 7200), Faculty of Pharmacy, University of Strasbourg - CNRS, Illkirch, France, Tel: 33368854141; E-mail: desaubry@unistra.fr

Embarek Bentouhami, Faculty of Technology, University Ferhat Abbas, Sétif, Algeria, Tel: 21336611194; E-mail: setlab19@gmail.com

Received May 02, 2017; Accepted May 09, 2017; Published May 15, 2017

Citation: Tabti R, Tounsi N, Gaiddon C, Bentouhami E, Désaubry L (2017) Progress in Copper Complexes as Anticancer Agents. Med Chem (Los Angeles) 7: 875879. doi: 10.4172/2161-0444.1000445

Copyright: ( 2017 Tabti R, et al. This is an open-access article distributed under the terms of the Creative Commons Attribution License, which permits unrestricted use, distribution, and reproduction in any medium, provided the original author and source are credited. 
Citation: Tabti R, Tounsi N, Gaiddon C, Bentouhami E, Désaubry L (2017) Progress in Copper Complexes as Anticancer Agents. Med Chem (Los Angeles) 7: 875-879. doi: 10.4172/2161-0444.1000445

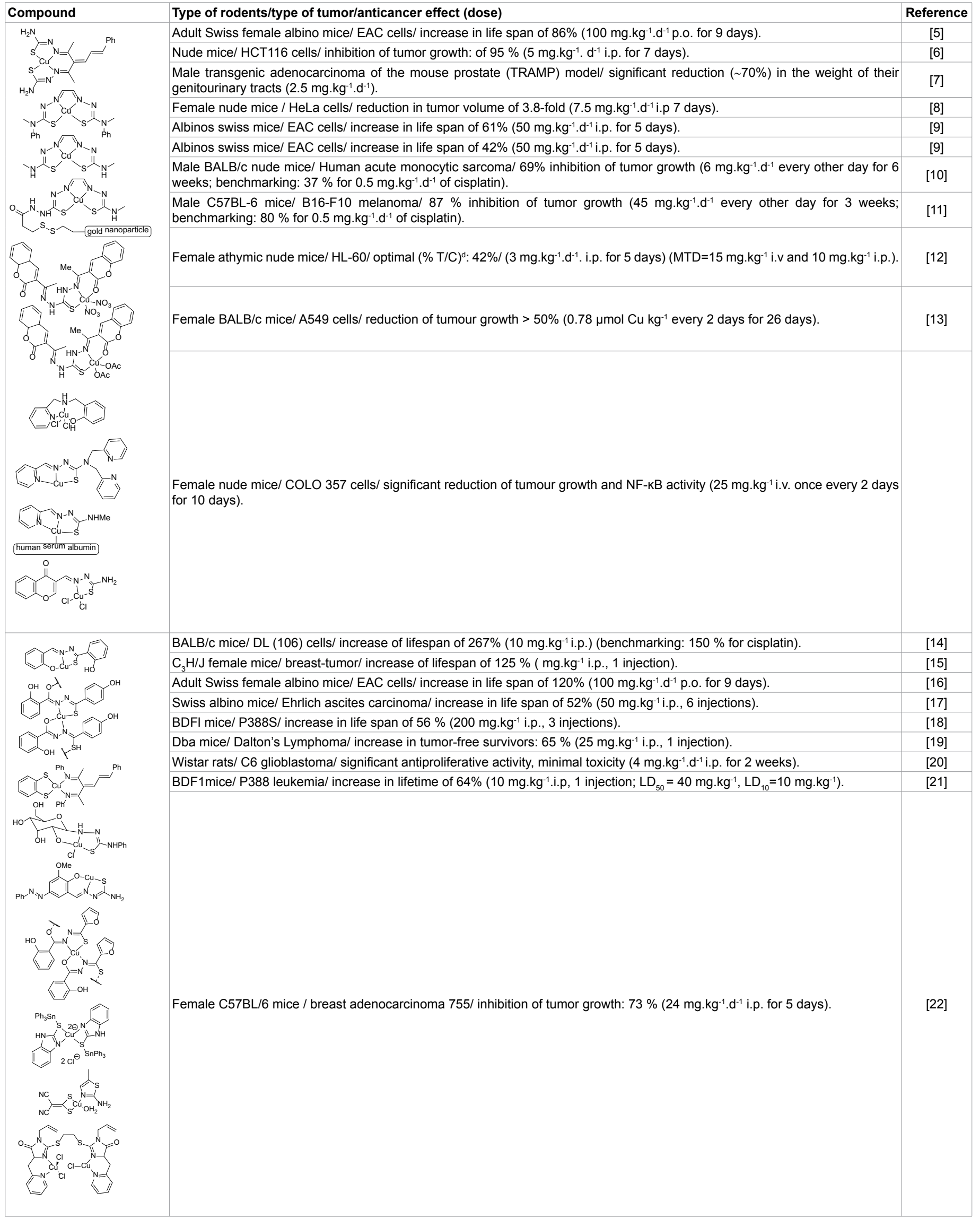


Male BALB/c/nude mice/ HepG2 cells/ tumor inhibition rate: $66 \%$ (4 mg. $\mathrm{kg}^{-1} \mathrm{i} . \mathrm{p}$. for 3 weeks).

Wister Albino rats/mammary carcinoma/ inhibition of tumor growth (4.3 mg.kg-1 i.p. 5 injections)

Table 1: Copper complexes that display antitumor effects in mouse models of cancers.

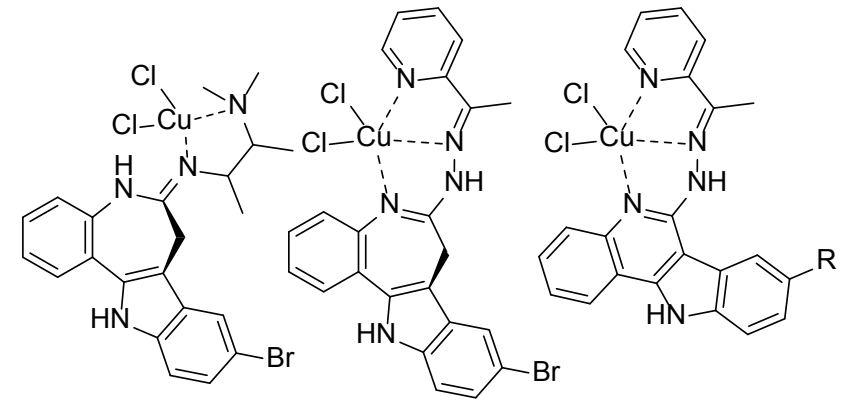

Figure 1: Representative examples of cytotoxic paullone analogues conjugated to $\mathrm{Cu}(\mathrm{II})$ [44].

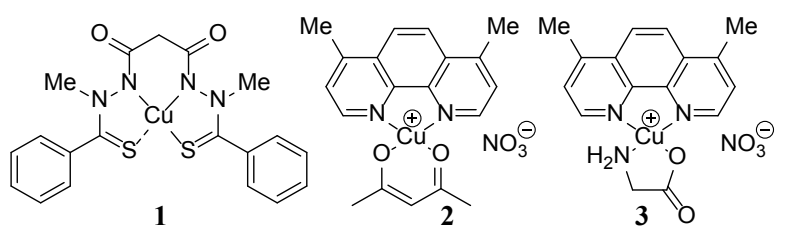

Figure 2: $\mathrm{Cu}(\mathrm{II})$ Elesclomol (1), Casiopeínas IIlia and II-Gly (2 et 3).

by previous review. By focusing on in vivo data, we aim at providing a critical overview of the most promising anticancer copper complexes.

On the opposite of classical anticancer drugs that display a high selectivity for their molecular target, copper complexes affect DNA and a myriad of proteins to induce a general toxicity that is lethal to cancer cells. Due to its ability to participate in redox reactions, copper is able to produce large amounts of ROS through a Fenton-like reaction to damage DNA and proteins [50].

Over the last two decades, copper complexes have consolidated their place in medicinal chemistry, which is manifested by an increased number of compounds that showed their efficacy in animal models of cancers (Table 1). Two of these drugs have been examined in clinical trial (Figure 2). The first one, elesclomol, synthesized as complex with $\mathrm{Cu}(\mathrm{II})$, has entered a phase I clinical trial to treat acute myeloid leukemia where it displayed a very favorable safety profile, but unfortunately no clinical results at the maximal evaluated dose of $400 \mathrm{mg} / \mathrm{m}^{2}$ [53]. This drug has also been examined in a phase II trial against ovarian, fallopian, and peritoneal cancers [54]. Importantly, it was demonstrated to exert its anticancer activity as a complex with $\mathrm{Cu}(\mathrm{I})$, indicating that elesclomol is in fact a prodrug [55,56]. Regarding its mechanism of action, it seems to be similar to other cytotoxic copper chelating compounds based on a NCI COMPARE analysis [56]. Elesclomol binds to $\mathrm{Cu}(\mathrm{II})$ in the serum, which get reduced to $\mathrm{Cu}(\mathrm{I})$ once inside cancer cells, where it induces DNA double strand breaks and catalyzes the formation of ROS in a larger amount that in non-cancer cells, explaining why this drug is more cytotoxic to malignant cells than to normal ones $[57,58]$.

Another drug, Casiopeína IIIia has also entered a phase I clinical trial against acute myeloid leukemia [59]. This agent induces DNA fragmentation and base oxidation, indicating that its mode of action involves reactive oxygen species (ROS) generation after copper reduction. Recently, Hernández-Lemus and coll. used transcriptomic approaches and pathway analysis tools to demonstrate that a novel analogue that is ready to start clinical phase I, Casiopeína II-Gly, enhances the metabolism of metal ions and block the migration and proliferation of HeLa cells [45]. A similar approach was recently used to identify metabolic signaling pathways deregulated by a novel ruthenium organometallic compound with interesting anticancer properties [60]. These works illustrate well how advanced techniques in metalloproteomics and system biology are expected to enlighten the mechanism of action of metallodrugs in a close future [61].

\section{Conclusion}

Preclinical and clinical studies have gathered encouraging evidences to endorse the therapeutic potential of copper complexes. The main benefit of copper complexes lies on their ability to be selectively reduced as $\mathrm{Cu}(\mathrm{I})$ complexes in malignant cells to induce cell death. The goal is now to move from compounds that were originally designed for their catalytic or physical properties to more drug-like compounds that display improved in vivo pharmacological properties. One of the challenges to develop this class of drugs is to deal with the complexity of their mechanism of action that does not involved a single molecular target. Thanks to the development of new technologies to explore the effects on every signaling pathway, this limitation is under implementation and we expect that more drug candidates will be soon examined in clinical trials.

\section{Acknowledgements}

This work was supported by the "Association pour la Recherche sur le Cancer" (ARC) and "Campus France" for a Tassili fellowship to RT.

\section{References}

1. Mjos KD, Orvig C (2014) Metallodrugs in medicinal inorganic chemistry. Chem Rev 114: 4540-4563.

2. Graf N, Lippard SJ (2012) Redox activation of metal-based prodrugs as a strategy for drug delivery. Adv Drug Deliv Rev 64: 993-1004.

3. Schwartz L, Supuran CT, Alfarouk KO (2017) The Warburg Effect and the Hallmarks of Cancer. Anticancer Agents Med Chem 17: 164-170.

4. Kim BE, Nevitt T, Thiele DJ (2008) Mechanisms for copper acquisition, distribution and regulation. Nat Chem Biol 4: 176-185.

5. Raman N, Jeyamurugan R, Rajkapoor B, Magesh V (2009) Metal-based antitumor, cytotoxic and antimicrobial activity: pharmacological evaluation of Knoevenagel condensate $\beta$-diketone Schiff base thiosemicarbazone $\mathrm{Cu}$ (II) and Zn (II) complexes. Applied Organometallic Chemistry 23: 283-290.

6. Palanimuthu D, Shinde SV, Somasundaram K, Samuelson AG (2013) In vitro 
and in vivo anticancer activity of copper bis(thiosemicarbazone) complexes. J Med Chem 56: 722-734.

7. Cater MA, Pearson HB, Wolyniec K, Klaver P, Bilandzic M, et al. (2013) Increasing Intracellular Bioavailable Copper Selectively Targets Prostate Cancer Cells. ACS Chem Biol 8: 1621-1631.

8. Pramanik AK, Palanimuthu D, Somasundaram K, Samuelson AG (2016) Biotin Decorated Gold Nanoparticles for Targeted Delivery of a Smart-linked Anticancer Active Copper Complex: In Vitro and In Vivo Studies. Bioconjug Chem 27: 2874-2885.

9. Sathisha MP, Shetti UN, Revankar VK, Pai KS (2008) Synthesis and antitumor studies on novel $\mathrm{Co}$ (II), Ni (II) and Cu (II) metal complexes of bis (3-acetylcoumarin) thiocarbohydrazone. Eur J Med Chem 43: 2338-2346.

10. Borges LJ, Bull ÉS, Fernandes C, Horn A, Azeredo NF, et al. (2016) Resende JA, Freitas WR, Carvalho EC, Lemos LS, Jerdy H, Kanashiro MM. In vitro and in vivo studies of the antineoplastic activity of copper (II) compounds against human leukemia THP-1 and murine melanoma B16-F10 cell lines. Eur J Med Chem, 123: 128-140.

11. Hancock CN, Stockwin LH, Han B, Divelbiss RD, Jun JH, et al. (2011) A copper chelate of thiosemicarbazone NSC 689534 induces oxidative/ER stress and inhibits tumor growth in vitro and in vivo. Free Radic Biol Med 50: 110-121.

12. Qi J, Zhang Y, Gou Y, Zhang Z, Zhou Z, et al. (2016) Developing an anticancer copper (II) pro-drug based on the His242 residue of the human serum albumin carrier IIA subdomain. Mol Pharm 13: 1501-1507.

13. Barve V, Ahmed F, Adsule S, Banerjee S, Kulkarni S, et al. (2006) Synthesis, molecular characterization, and biological activity of novel synthetic derivatives of chromen-4-one in human cancer cells. J Med Chem 49: 3800-3808.

14. Shrivastav A, Singh NK, Singh SM (2002) Synthesis, characterization and antitumor studies of Mn (II), Fe (III), Co (II), Ni (II), Cu (II) and Zn (II) complexes of N-salicyloyl-N'-o-hydroxythiobenzhydrazide. Bioorg Med Chem 10: 887-895.

15. Singh NK, Singh N, Prasad GC, Sodhi A, Shrivastava A (1997) Antitumor activity studies of newly synthesized $\mathrm{N}$-salicyloyl-N'-(p-hydroxybenzthioyl) hydrazine and its copper (II) complex both in vivo and in vitro. Bioorg Med Chem 5: 245-251.

16. Raman N, Jeyamurugan R, Senthilkumar R, Rajkapoor B, Franzblau SG (2010) In vivo and in vitro evaluation of highly specific thiolate carrier group copper (II) and zinc (II) complexes on Ehrlich ascites carcinoma tumor model. Eur J Med Chem 45: 5438-5451.

17. Sathisha MP, Budagumpi S, Kulkarni NV, Kurdekar GS, Revankar VK, et al. (2010) Synthesis, structure, electrochemistry and spectral characterization of (d-glucopyranose)-4-phenylthiosemicarbazide metal complexes and their antitumor activity against Ehrlich Ascites Carcinoma in Swiss albino mice. Eur J Med Chem 45: 106-113.

18. Patil BG, Havinale BR, Shallom JM, Chitnis MP (1989) Syntheses and spectroscopic studies of potential antitumor copper (II) complexes with 5-phenylazo-3-methoxy salicylidene thiosemicarbazone and N4 substituted thiosemicarbazones. J Inorg Biochem 36: 107-113.

19. Agrawal S, Singh NK, Aggarwal RC, Sodhi A, Tandon P (1986) Synthesis structure, and antitumor activity of N-salicyloyl-N'-(2-furylthiocarbonyl) hydrazine and its copper(II) complex. J Med Chem 29: 199-202.

20. Höti N, Zhu DE, Song Z, Wu Z, Tabassum S, et al. (2004) p53-dependent apoptotic mechanism of a new designer bimetallic compound tri-phenyl tin benzimidazolethiol copper chloride (TPT-CuCl2): in vivo studies in Wistar rats as well as in vitro studies in human cervical cancer cells. J Pharmacol Exp Ther 311: 22-33.

21. Bolos CA, Chaviara AT, Mourelatos D, lakovidou Z, Mioglou E, et al. (2009) Synthesis, characterization, toxicity, cytogenetic and in vivo antitumor studies of 1, 1-dithiolate $\mathrm{Cu}$ (II) complexes with di-, tri-, tetra-amines and 1, 3-thiazoles. Structure-activity correlation. Bioorg Med Chem 17: 3142-3151.

22. Majouga AG, Zvereva MI, Rubtsova MP, Skvortsov DA, Mironov AV, et al (2014) Mixed Valence Copper(I,II) Binuclear Complexes with Unexpected Structure: Synthesis, Biological Properties and Anticancer Activity. J Med Chem 57: 6252-6258

23. Jia L, Xu J, Zhao X, Shen S, Zhou T, et al. (2016) Synthesis, characterization, and antitumor activity of three ternary dinuclear copper (II) complexes with a reduced Schiff base ligand and diimine coligands in vitro and in vivo. $\mathrm{J}$ Inorg Biochem 159: 107-119.

24. Carvallo-Chaigneau, F, Trejo-Solís C, Gómez-Ruiz C, Rodríguez-Aguilera E,
Macias-Rosales L, et al. (2008) Casiopeina III-ia induces apoptosis in HCT-15 cells in vitro through caspase-dependent mechanisms and has antitumor effect in vivo. BioMetals 21: 17-28.

25. Etaiw SE, Sultan AS, El-bendary MM (2011) In vitro and in vivo antitumor activity of novel 3D-organotin supramolecular coordination polymers based on CuCN and pyridine bases. J Organomet Chem 696: 1668-1676.

26. Chakraborty A, Kumar P, Ghosh K, Roy P (2010) Evaluation of a Schiff base copper complex compound as potent anticancer molecule with multiple targets of action. Eur J Pharmacol 647: 1-12.

27. Chaviara AT, Christidis PC, Papageorgiou A, Chrysogelou E, Hadjipavlou-Litina DJ, et al. (2005) In vivo anticancer, anti-inflammatory, and toxicity studies of mixed-ligand $\mathrm{Cu}(\mathrm{II})$ complexes of dien and its Schiff dibases with heterocyclic aldehydes and 2-amino-2-thiazoline. Crystal structure of [Cu(dien)(Br) (2a-2tzn)](Br)(H2O). J Inorg Biochem 99: 2102-2109.

28. Jantova S, Durackova Z, Novotny L, Urbancikova M, Dovinova I, et al. (1998) Macrocyclic $\mathrm{Cu}(\mathrm{II})$ tetraanhydroaminobenzaldehyde complex--antiproliferative activity in vitro and in vivo. Neoplasma 45: 254-260.

29. Singh UP, Singh BN, Ghose AK, Singh RK, Sodhi A (1991) Synthesis, characterization, and antitumor activity of 5-iodouracil complexes. J. Inorg. Biochem 44: 277-282.

30. Berners-Price SJ, Johnson RK, Mirabelli CK, Faucette LF, McCabe FL, et al (1987) Copper(I) complexes with bidentate tertiary phosphine ligands: solution chemistry and antitumor activity. Inorg Chem 26: 3383-3387.

31. Gandin V, Tisato F, Dolmella A, Pellei M, Santini C, et al. (2014) In vitro and in vivo anticancer activity of copper(I) complexes with homoscorpionate tridentate tris(pyrazolyl)borate and auxiliary monodentate phosphine ligands. J Med Chem 57: 4745-4760.

32. Díez M, Arroyo M, Cerdàn FJ, Muñoz M, Martin MA, et al. (1989) Serum and tissue trace metal levels in lung cancer. Oncology 46: 230-234.

33. Geraki K, Farquharson MJ, Bradley DA (2002) Concentrations of Fe, Cu and $\mathrm{Zn}$ in breast tissue: a synchrotron XRF study. Phys. Med Biol 47: 2327-2339.

34. Nayak SB, Bhat VR, Upadhyay D, Udupa SL (2003) Copper and ceruloplasmin status in serum of prostate and colon cancer patients. Indian J Physio Pharmacol 47: 108-110.

35. Yoshida D, Ikeda Y, Nakazawa S (1993) Quantitative analysis of copper, zinc and copper/zinc ratio in selected human brain tumors. J Neurooncol 16: 109-115.

36. Gupta SK, Shukla VK, Vaidya MP, Roy SK, Gupta S (1991) Serum trace elements and $\mathrm{Cu} / \mathrm{Zn}$ ratio in breast cancer patients. J Surg Oncol 46: 178-181.

37. Rigiracciolo DC, Scarpelli A, Lappano R, Pisano A, Santolla MF, et al. (2015) Copper activates HIF-1 1 I/GPER/VEGF signalling in cancer cells. Oncotarget 6: 34158-34177.

38. Liang Y, Ewing PM, Laursen WJ, Tripp VT, Singh S, et al. (2014) Copperbinding properties of the BIR2 and BIR3 domains of the X-linked inhibitor of apoptosis protein. J Inorg Biochem 140: 104-110.

39. Mufti AR, Burstein E, Duckett CS (2007) XIAP: cell death regulation meets copper homeostasis. Arch Biochem Biophys 463: 168-174

40. Brady DC, Crowe MS, Turski ML, Hobbs GA, Yao X, et al. (2014) Copper is required for oncogenic BRAF signalling and tumorigenesis. Nature 509: 492-496.

41. Turski ML, Brady DC, Kim HJ, Kim BE, Nose Y, et al. (2012) A novel role for copper in Ras/mitogen-activated protein kinase signaling. Mol Cell Biol 32: 1284-1295.

42. Barthel A, Ostrakhovitch EA, Walter PL, Kampkötter A, Klotz LO (2007) Stimulation of phosphoinositide 3-kinase/Akt signaling by copper and zinc ions: mechanisms and consequences. Arch Biochem Biophys 463: 175-182.

43. Ostrakhovitch EA, Lordnejad MR, Schliess F, Sies H, Klotz LO (2002) Copper ions strongly activate the phosphoinositide-3-kinase/Akt pathway independent of the generation of reactive oxygen species. Arch Biochem Biophys 397: 232-239.

44. Primik MF, Göschl S, Jakupec MA, Roller A, Keppler BK, et al. (2010) Structureactivity relationships of highly cytotoxic copper(II) complexes with modified indolo[3,2-c]quinoline ligands. Inorg Chem 49: 11084-11095.

45. Espinal-Enríquez J, Hernández-Lemus E, Mejía C, Ruiz-Azuara L (2015) Network Analysis Shows Novel Molecular Mechanisms of Action for CopperBased Chemotherapy. Front Physiol 6: 406. 
Citation: Tabti R, Tounsi N, Gaiddon C, Bentouhami E, Désaubry L (2017) Progress in Copper Complexes as Anticancer Agents. Med Chem (Los Angeles) 7: 875-879. doi: 10.4172/2161-0444.1000445

46. Krajčiová D, Melník M, Havránek E, Forgácsová A, Mikuš P (2014) Copper compounds in nuclear medicine and oncology. J Coord Chem 67: 1493-1519.

47. Marzano C, Pellei M, Tisato F, Santini C (2009) Copper complexes as anticancer agents. Anticancer Agents Med Chem 9: 185-211.

48. PatersonBM, DonnellyPS(2011)Coppercomplexes of bis(thiosemicarbazones): from chemotherapeutics to diagnostic and therapeutic radiopharmaceuticals. Chem Soc Rev 40: 3005-3018.

49. Ruiz-Azuara L, Bravo-Gómez ME (2010) Copper compounds in cancer chemotherapy. Curr Med Chem 17: 3606-3615.

50. Santini C, Pellei M, Gandin V, Porchia M, Tisato F, et al. (2014) Advances in copper complexes as anticancer agents. Chem Rev 114: 815-862.

51. Tan SJ, Yan YK, Lee PP, Lim KH (2010) Copper, gold and silver compounds as potential new anti-tumor metallodrugs. Future Med Chem 2: 1591-1608.

52. Tardito S, Marchiò L (2009) Copper compounds in anticancer strategies. Curr Med Chem 16: 1325-1348.

53. Hedley D, Shamas-Din A, Chow S, Sanfelice D, Schuh AC, et al. (2016) A phase I study of elesclomol sodium in patients with acute myeloid leukemia. Leuk Lymphoma 57: 2437-2440.

54. NIH Elesclomol Sodium and Paclitaxel in Treating Patients with Recurrent or Persistent Ovarian Epithelial Cancer, Fallopian Tube Cancer, or Primary Peritoneal Cancer. https://clinicaltrials.gov/ct2/show/NCT00888615?term=Ele sclomol\&rank=3
55. Hasinoff BB, Yadav AA, Patel D, Wu X (2014) The cytotoxicity of the anticancer drug elesclomol is due to oxidative stress indirectly mediated through its complex with $\mathrm{Cu}(\mathrm{II})$. J Inorg Biochem 137: 22-30.

56. Hasinoff BB, Wu X, Yadav AA, Patel D, Zhang H, et al. (2015) Cellular mechanisms of the cytotoxicity of the anticancer drug elesclomol and its complex with $\mathrm{Cu}(\mathrm{II})$. Biochem Pharmacol 93: 266-276.

57. Blackman RK, Cheung-Ong K, Gebbia M, Proia DA, He S, et al. (2012) Mitochondrial electron transport is the cellular target of the oncology drug elesclomol. PLoS One 7: e29798.

58. Kirshner JR, He S, Balasubramanyam V, Kepros J, Yang CY, et al. (2008) Elesclomol induces cancer cell apoptosis through oxidative stress. Mol Cancer Ther 7: 2319-2327.

59. Ruiz-Azuara L, Bastian G, Bravo-Gómez ME, Cañas RC, Flores-Alamo M et al. (2014) Abstract CT408: Phase I study of one mixed chelates copper(II) compound, Casiopeína Caslllia with antitumor activity and its mechanism of action. Cancer Res 74: CT408-CT408.

60. Licona C, Spaety ME, Capuozzo A, Ali M, Santamaria R, e al. (2017) A ruthenium anticancer compound interacts with histones and impacts differently on epigenetic and death pathways compared to cisplatin. Oncotarget 8: 2568-2584.

61. Fu D, Finney L (2014) Metalloproteomics: challenges and prospective for clinical research applications. Expert Rev Proteomics 11: 13-19. 